\title{
A TUdós TANÁr, MiKa SÁNDOR
}

\author{
ALbERT B. GÁbOR * - BENCÉNÉ FEKETE ANDREA ** \\ - GARAI IMRE ${ }^{* * *}$ - KATONA ANDRÁS \\ * a Kaposvári Egyetem Pedagógiai Kar Neveléstudományi Tanszék \\ adjunktusa \\ albert.gabor@ke.hu \\ ** a Kaposvári Egyetem Pedagógiai Kar Neveléstudományi Tanszék \\ docense \\ fekete.andrea@ke.hu \\ *** az Eötvös Loránd Tudományegyetem Pedagógiai és Pszichológiai Kar \\ tanársegédje, \\ az Eötvös József Collegium \\ seniora \\ **** az Eötvös Loránd Tudományegyetem Bölcsészettudományi Karának \\ ny. föiskolai docense \\ katona.andras@btk.elte.hu
}

A modern tanártípust, Mika Sándort, Glatz Ferenc írását követve jellemezhetjük (Glatz, 1989, 42-43. o.). Mika Sándor erdélyi értelmiségi-tisztviselő családból származott, a bölcselet elvégzését követően 1879-ben Kolozsvárott magántanár lett. Szilágyi Sándor egyik kiválasztottjaként európai szemináriumokon vett részt. Egyetemes történelemmel foglalkozott, tanári munkáján - a tradicionális német irodalom hatókörén túllépve - mindvégig érződött a francia kultúra hatása. A brassói föreáliskolában, majd a VII. kerületi fógimnáziumban, 1895-től a gyakorló gimnáziumban tanított. Tudós tanári pályája az Eötvös Collegiumban teljesedett ki. (Glatz, 1989, 42-43. o.)

Írásunk az Eötvös Collegium első történész szakvezetöje, Mika Sándor tevékenységének több irányú bemutatására vállalkozik. Az Eötvös Collegium Mednyánszky Dénes Könyvtár és Levéltár iratanyagaira támaszkodva egyrészt Mika Sándor internátusbeli - elsősorban az Eötvös Collegium korai szakaszában kifejtett - munkásságát mutatja be, másrészt Mika történelemtanítási módszereinek, az általa használt tantárgyi segédeszközöknek, valamint egy eddig feltáratlan tantárgytörténeti téma, a Mika-olvasókönyvek bemutatását tekinti feladatának. A századelőn (1902) írt Mika-féle egyetemes történeti tankönyveket a húszas évek második felében Marczinkó Ferenc középiskolai tanár dolgozta át. Az iskolai értesítők tankönyvhasználati adatösszesítésére alapozva igazoljuk ezeknek a tankönyveknek a tartósságát, a klebelsbergi időszakban való továbbélését. A tanulmány kerete lehetőséget 
ad a Mika-féle olvasókönyvek áttekintése mellett a Mika-Marczinkó-féle egyetemes történeti tankönyvek bemutatására is.

Mika Sándornak, az Eötvös Collegium első történész szakvezetőjének korai tevékenységéről kevés forrás áll rendelkezésre. Annyi bizonyos, hogy az 1895-1896. tanévben két történelem szakos tanítványa volt: Madzsar Imre, illetve Tompa József. Utóbbi azonban betegség folytán 1896. március 21-én elhunyt. ${ }^{1}$ Madzsarnak föleg a latin, francia és német nyelvekben kellett magát tökéletesítenie, hogy a történeti forrásokat és a szakmunkákat folyékonyan tudja olvasni. Jelentésében már ekkor kiemelte a Collegium könyvtárát, amelynek történeti részlege is páratlan lehetőségeket biztosított az intézet neveltjei számára. A történész szakosok mellett a magyar irodalomtörténeti tanulmányokat folytató collegistáknak is látogatniuk kellett óráit, így tanítványai között megtalálható az ifjú Gombocz Zoltán is. ${ }^{2}$

A Collegium valamennyi szakvezetöjéhez hasonlóan Mika Sándor célja is az volt, hogy történész tanítványait a másodév végén esedékes alapvizsgára felkészítse. Munkamódszeréről az 1904-1905. tanévtől állnak rendelkezésre források.

Az első évesek rendszerint az Árpád-ház első uralkodóinak törvényszövegeit (Szent István, Szent László, Kálmán, II. András), ${ }^{3}$ esetleg egyéb történeti emlékeket (Anonymus Gestáját, a Hartvik-féle Szent István legendát, a Gellért legendát, valamint Kézai Simon Gesta Hungarorumát) olvasták át tüzetesen. Ezek mellett minden esetben az ókori görög és római történelmet is tanulmányozták. ${ }^{4}$

A másodévesek a $I V$. Bélát követő uralkodók jogalkotását tekintették át rendszerint az Anjou-kor végéig vizsgálva a törvénykezést. Theodore Mommsen (Römischen Geschichte I-III. kötet) és Eduard Meyer munkáin keresztül a római alkotmánytörténettel is foglalkoztak. ${ }^{5}$ Mommsen és Meyer, illetve Charles Seignobos Introduction aux études historiques (Bevezetés a történeti tanulmányokba), valamint Karl Julius Beloch mindannyiukat kritizáló munkásságának megismertetésével nyilvánvalóan fiatal tanítványainak szemléletét, a történeti megismerés határait akarta bemutatni, a korban elérhető modern irodalmak segítségével (Romsics, 2011, 75-76. o.; Glatz, 1989, 44. o.; Albert B., 2006, 49. o.; Biriszló és Szabó, 2012, 2. o.).

A harmadévesek föleg krónikák olvasásán keresztül tanulmányozták a középkori egyetemes történelmet: referálniuk kellett Einhardus, Freisingi Ottó, Joinville,

\footnotetext{
${ }^{1}$ Tompa József személyi anyagai. MDKL 21. doboz 20. dosszié 61. csomó.

${ }^{2}$ Mika Sándor jelentése a történelem szakórákról az 1895/1896. tanévben. Budapest, 1896. június 12. MDKL 52. doboz 101/a. dosszié.

${ }^{3}$ Mika Sándor jelentése a történelem szakórákról az 1904/1905. tanévben. Budapest, 1905 júniusa. MDKL 52. doboz 101/b. dosszié.

${ }^{4}$ Mika Sándor jelentése a történelem szakórákról az 1906/1907. tanévben. Budapest, 1907. június 7. MDKL 52. doboz 101/c. dosszié.

${ }^{5}$ Mika Sándor jelentése a történelem szakórákról az 1905/1906. tanévben. Budapest, 1906. június 1. 52. doboz 101/c. dosszié.
} 
Froissart, vagy éppen Geoffry de Villehardouin krónikáiból, amelyek kapcsán az egyetemes eseménytörténeti kérdéseket is megtárgyalták. (Vö. Szekfü, Sine anno. 9. o.) ${ }^{6}$

Az újkori történelmet a negyedévesek az egyetemen hallgatták, a collegiumi képzésben nem kellett részt venniük, ${ }^{7}$ Mika csupán szakdolgozatuk elkészítésének egyes fázisait felügyelte. ${ }^{8}$ Tanítványaitól megkövetelte, hogy a francia irodalomban is tájékozódjanak, így olvastatta Balzac, Stendhal, Flaubert müveit, illetve a nagy francia forradalomról összefoglaló munkát készítő szerzőket: Mignet, Quinet és Michelet, Thiers, Thaine (Szekfü, Sine anno. 5. o.).

Hangsúlyt nem csupán a német filológiai módszerre helyezett, hanem tárgyalásába bevonta az elismert francia szerzők újszerü müveit is, ezek ütköztetésével, illetve az egyéni feldolgozáson alapuló rendszeres beszámolók kérésével a kritikus gondolkodás fejlesztésére ösztönözte a collegistákat (Biriszló és Szabó, 2012, 2. o.). Így a Collegiumban egy polgári szemléletmódot kialakító történész mühely jött létre, amelynek tagjai közül nem csupán számos iskolateremtő egyéniség emelkedett ki, de az addigi nemesi szemléletmódot meghaladni nem tudó magyar történetírásba új, formabontó kérdéseket is felvetettek (Glatz, 1989, 44-45. o.). ${ }^{9}$

Mika Sándor az Eötvös Collegium szemináriumain olyan modern módszertani eszköztárat adott át diákjainak, amellyel eredményesebbé, érdekesebb tehették a történelemórákat, és amit ök is továbbörökíthettek az utókornak. Történelemtanítási módszerének újdonsága nem csak a modern módszertani eszköztár és tantárgyi segédeszközök alkalmazásában állt; nem csak tanított, információt közvetített, hanem bátran felvállalta történésznevelői munkásságát is. A történésztanárokat szabadságszeretetre, reális, csendes, kritikai szemléletre nevelte. (Szekfü, 2001, 170. o.)

Az Eötvös Collegiumban a föként segédtudományi ismeretek elsajátítására irányuló történelemtanítás nem az adatok megtanulására, hanem azok elemzésére, értelmezésére irányult. Mika Sándor mesterségbeli, technikai fogások elsajátítására ösztönözte tanítványait. Külföldi tanulmányai során elsajátított európai látásmódjával formálta a Collegium új szellemi irányvonalát. Megtanította növendékeit a forrásolvasás, a forráselemzés müvészetére. (Glatz, 1989, 42. o.)

Az eredeti források olvasása és elemzése segítségével ismerték meg a diákok múltjuk legfontosabb eseményeit, nagy hangsúlyt helyezve a magyar történelem valósághủ megismerésére.

\footnotetext{
${ }^{6}$ Mika Sándor jelentése a történelem szakórákról az 1904/1905. tanévben. Budapest, 1905 júniusa. MDKL 52. doboz 101/b. dosszié.

${ }^{7}$ Ez általános volt a Collegium többi tanszakán is. A negyedévesek képzésbe való bevonására elöször a klasszika-filológia területén történt meg az I. világháborút követő tanulmányi válság nyomán. Ezt követte az 1920-as évek közepére az intézet valamennyi szakvezetője.

${ }^{8}$ Mika Sándor jelentése a történelem szakórákról az 1907/1908. tanévben. Budapest, 1908. május 29. MDKL 52. doboz 101/c. dosszié.

${ }^{9}$ Ennek a formabontó szemléletnek az egyik első produktuma Szekfü Gyula 1913-ban megjelent Száműzött Rákóczi címủ munkája, amelynek bizonyos megállapításai kiváltották a korabeli történészek heves kritikáját (Romsics, 2011, 279-280. o.).
} 
Szekfü Gyula (2001) az Eötvös Collegiumban ismerte meg Mika Sándort, aki „csendes, szelíd szavú, szelíd pillantású" tanár volt. Olyan vezetőtanár, aki megnyitotta otthonát a collegisták előtt, aki a magánkönyvtárában az iskolán kívüli müvelödés lehetőségét is biztosította tanítványai számára. Nem politizált, a dolgokat, a világ eseményeit reálisan szemlélte és értékelte. A magyarság életében bekövetkező eseményeket kritikusan szemlélte ugyan, de nem lépett fel ellenük, kizárólagosan saját körében juttatta kifejezésre meggyőződését, a jövő nemzedékének szemléletformálása érdekében.

Az olvasókönyv, mint taneszköz-müfaj hazai keletkezéstörténetében Mika Sándor kulcsszerepe szintén megkérdőjelezhetetlen.

Az első próbálkozás, amely már magyar történelmi szöveggyüjteménynek tekinthetö, Hanthó Lajos Olvasókönyv a hazai történelmet tárgyaló összes könyvekhez címü, 1874-ben kiadott munkája volt, mely 54, értékelés nélküli, eléggé esetlegesen válogatott egykorú forrást és történetírói feldolgozást közölt.

A XIX. század végi történelemtanításban a források, korabeli szóhasználattal a „,kútfő"k” egyre elterjedő használata újdonságnak számított. A VIII. osztályban Magyarország története tanítását, ,tekintettel a társadalmi és állami viszonyok fejlődésére, a kútfőknek s a történetírásnak ismertetésével" (A magy. kir. vallás- és közoktatásügyi miniszter 1879. évi 17630. sz. a. kelt rendelete) rendelték el az 1879-es tantervben. Talán nem meglepő, hogy ennek az egyik első szorgalmazója a didaktikus és oktatásszervező - tehát nem történelemtanár vagy - tudós, az 1879-es tanterv első számú megalkotója - Kármán Mór volt: „Elvárható ... a történelem tanárainak buzgalmától, hogy egyes jellemző koriratokat, különösen az ó- és középkor történetére vonatkozókat ... az ifjúság hasznára olyaténképen fel fognak dolgozni, hogy azok magánolvasmánykép a tanítást kisérve, a növendékek történeti ismeretei bővítésére s még inkább történeti érzékök emelésére szolgáljanak." (Kármán, 1909, 275-276. o. $)^{10}$ Az 1885-ben ülésező Országos Történeti Kongresszus határozatainak 2. pontjában pedig kimondta, hogy ,... fontosnak nyilvánítja, hogy az ifjúsági könyvtárak, esetleg a magyar történelmi társúlat és az orsz. Tanáregyesület vegyes bizottsága által szerkesztendő s a tanügyi kormány által szabályszerüen jóváhagyandó kútföket s magyar történelmi olvasókönyveket kellö számmal szerezzenek be, s hogy azok a VI-VIII. osztályokban kötelező magánolvasmányokúl szolgáljanak." (Szádeczky, 1885, 189-190. o. kiemelés a szerzőktől.)

A határozat végrehajtására a kor egyik vezető történésze, Marczali Henrik kapott megbízást. Ennek eredménye a Márki Sándor és Angyal Dávid segítségével tanárok és tanárjelöltek számára 1901-ben elkészült, „, A magyar történelem kútföi-

\footnotetext{
${ }^{10}$ Nem véletlen tehát, hogy az 1905-ben megjelenő Magyar történelmi olvasókönyv I. részének (kötetének) Előszavát is Kármán Mór írta. Ebből az inkább útmutatásból idézünk: „Belé helyezni ... növendékeinket a múlt idők közhangulatába, hogy rokon érzéssel kísérje még tévelygő utjaikon is küzdő őseit: ez a történeti tanításnak első teendője, helyes tapasztalati alapja.” (Magyar történelmi olvasókönyv I. rész, 1905. VI.).
} 
nek kézikönyve” című munka. A gyakorló középiskolai tanár Mika Sándorban is ez idő tájt fogalmazódhatott meg az igény, hogy mindebből a diákok számára is hozzáférhető forrásokat tegyen közzé.

A terv 1905-től realizálódott. 1905 és 1907-ben két magyar történelmi olvasókönyv, 1908-1909-ben három világtörténeti, végül 1910-ben a sorozat zárókötete, újra egy magyar történelmi olvasókönyv látott napvilágot. A hat kötet 1207 oldalon összesen 158 eredeti történeti forrást tartalmazott. Mika Sándor segítőtársa a szemelvények összeállításában és fordításában Madzsar Imre, Szentpétery Imre, Szigeti Gyula és Szabó Dezső volt. A negyvenes évei végén és ötvenes éveinek elején járó föszerkesztő mellett valamennyien a húszas éveik végén és harmincas éveik elején járó fiatalemberek voltak. A szemelvények fordítói között is voltak neves történészek, például Szilágyi Sándor, Szekfü Gyula, Holub József, Eckhardt Ferenc.

A sorozat jelentőségét és használhatóságát mi sem bizonyítja jobban, mint hogy az 1960-as évekig - néhány 1940-es évekbeli elszigetelt próbálkozástól eltekintve - nem volt hasonló vállalkozás hazánkban. A hazai történelemtanításunk históriáján belül így alig lehet felülértékelni Mika Sándor olvasókönyv-sorozatának a jelentőségét. Nemcsak az elsőbbség okán, de immár évszázados „továbbélése” miatt sem. Még az 1960-es és 1970-as évek olvasókönyveiben is szép számban szerepeltek szó szerinti átvételek a Mika-féle olvasókönyvekböl.

Ez a korszakos jelentőségü olvasókönyv-sorozat a történelmi szemelvénygyüjtemények müfaji sajátosságait is meghatározta:

1. Csak elsődleges, a történeti kutatómunka során igazolt források kerültek a gyüjteménybe.

2. A történetírói feldolgozások és a történelmi tárgyú szépirodalmi szemelvények igénye felmerült ugyan néha a későbbi történelmi korszakokban is, de létjogosultságuk a mai napig nem igazolódott a történelmi olvasókönyvekben.

3. A magyar mellett egyetemes történeti szemelvényekre is szükség van, nagyjából fele-fele arányban.

4. A Hanthónál eredetileg tervezett képi szemléltetés, a rajzos ábrázolások végképp kimaradtak a történelmi olvasókönyvekböl.

5. Más tárgyakból (pl. irodalom, idegen nyelvek) is megjelentek olvasókönyvek, szemelvénygyüjtemények.

Érdemes áttekinteni Mika tankönyvének utóéletét is. Mika Sándor 1902-es egyetemes történeti tankönyvét az 1920-as évek második felében Marczinkó Ferenc középiskolai tanár dolgozta át. Az 1924-es középiskolai törvény és tanterv alapján megírt új tankönyv sorozatok első kötetei 1926-ban jöttek ki a nyomdából, melyet felmenő rendszerben 1931-ig bezáróan újabbak követtek. Ezek, a Lampel Kiadó gondozásában a tankönyvpiacra került sorozatok a harmincas évek elején a vidéki Magyarország állami és községi fiú középiskoláinak legkeresettebb sorozatainak szá- 
mítottak, megelözve a tankönyvpiaci versenyben a Szent István Társulat, valamint a kultusztárca által inkább támogatott Egyetemi Nyomda párhuzamos kiadványait.

24 budapesti iskolai értesítő áttekintése után a teljes, vagy többségében egy kiadó egyetemes történeti tankönyvsorozatát választó fiú középiskolából nyolc-nyolc a Mika-Marczinkó és a Marczell Ágoston-Szolomájer Tasziló könyveket használta, öt intézményben az Athenaeum kiadványai, az Ember István és Dékány István nevével fémjelzett munkák, két iskolában Domanovszky, egyben pedig a Madai Pál-féle sorozatok voltak forgalomban. Beszédes adatok ezek. Mutatják a Lampel és a Szent István Társulat egyetemes történeti sorozatai iránti megnövekedett keresletet. A Mika-Marczinkó sorozat elfogadottságát jelzi az is, hogy az állami és községi iskolák mellett felekezeti hovatartozástól függetlenül a fővárosban az egyik római katolikus és az egyik izraelita fenntartású fiú középiskola egyaránt az ő tankönyveiket választotta és az evangélikus fiú középiskolák számára is a választhatók körébe tartoztak ezek a kiadványok

A Mika-Marczinkó-féle sorozat tankönyvpiaci sikerét három tényező befolyásolhatta. Mika Sándor tankönyve (és a húzónév minden kétséget kizáróan Mika lehetett) két évtizede volt forgalomban, a hosszú ideig forgalomban lévő tankönyvektől pedig nem szívesen váltak meg az oktatók. A századelőn írt tankönyv bejáratottsága mellett az átdolgozott kiadványok szakmai színvonala is meghatározó volt. Az evangélikus fiú középiskolák számára az egyetemes tanügyi bizottság megbízásából Szigethy Lajos, a századelő népszerü tankönyvírója, az egyetemes tanügyi bizottság levelezö tagja is írt bírálatot. A bírálatok rámutatnak ezeknek a tankönyveknek a szakmai színvonalára is. Szigethy méltatta egy-egy korszak szemléletes bemutatására irányuló olvasmányokat. A középkori tankönyvböl példaként említette a Koránból vett szúrákat, Einhard Nagy Károly élete című múből vett részeket, Mika Lovaggá ütés, vagy Fináczy Kolostori élet fejezeteit. ${ }^{11}$ Néhány kritikai észrevételtől eltekintve Szigethy a IV. és az V. évfolyamok számára készült egyetemes történeti munkát szemléletében, életfelfogásában és felekezeti szempontból is kifogástalannak ítélte meg, így azokat egyházi engedélyezésre ajánlotta. ${ }^{12}$ Végül a Mika-Marczinkó tankönyvek liberális-közjogi szemlélete is erősen befolyásolhatta a dualizmus korának érvrendszerében szocializálódott és a klebelsbergi korszakban is igazgatóként, történelemtanárként dolgozó szakemberek tankönyv-preferenciáját.

\footnotetext{
${ }^{11}$ Evangélikus Országos Levéltár (továbbiakban EOL) Egyetemes Tanügyi Bizottság 9. doboz. Iratok 1930-1931, 17. csomó.

${ }^{12}$ Egyetlen kivételtől eltekintve. Szigethy számos kritikai észrevételt fogalmaz meg a szerzőpáros VI. osztályos tankönyvéről, melyek kizárólag a reformációval kapcsolatos fogalmakra, szempontokra vonatkoztak. Szigethy szerint csak alapos átfésülés és a helytelen kifejezések megváltoztatása után lehetne a tankönyvet az evangélikus tanulók számára használhatóvá tenni. EOL Egyetemes Tanügyi Bizottság 9. doboz. Iratok 1930-1931, 18. csomó.
} 


\section{Irodalom}

Albert B. Gábor (2006): Súlypontok és hangsúlyeltolódások. Középiskolai történelemtankönyvek a Horthy-korszakban. Pannon Egyetem, Pápa.

Albert B. Gábor (2010): A tankönyv-diplomácia cselekvéstere a két világháború közötti hazai tankönyvrevíziós mozgaomban. In: Kozma Tamás és Perjés Iván (szerk.): Új kutatások a neveléstudományban. Többnyelvüség és multikulturalitás. Aula Kiadó, Budapest. 329-336.

Általános utasítás a gymnasiumi tanítás tervéhez, 1880. In: Kármán Mór (1909) paedagógiai dolgozatai rendszeres összeállításban. II. köt. Budapest, 275-276.

A magy. kir. vallás- és közoktatásügyi miniszter 1879. évi 17630. sz. a. kelt rendeletével kiadott terv, módosítva az 1883. évi 26776. és az 1887. évi 8619. sz. a. kelt miniszteri rendeletekkel.

Angyal Dávid - Marczali Henrik - Mika Sándor (1901): Enchiridion fontium historiae Hungarorum. A magyar történet kútföinek kézikönyve. Szerk.: Marczali Henrik. Budapest.

A vallás- és közoktatásügyi miniszter 1892/6664. sz. rendelete görög és római írók olvastatásánál és a történelem tanításánál szükséges szemléltetőeszközökről.

A vallás- és közoktatásügyi m. kir. miniszternek a közoktatás állapotáról szóló és az országgyülés elé terjesztett huszonhetedik jelentése. Budapest, 1898, 83-84.

Balázs Györgyné (1970): Korkép kialakitása a történelemoktatásban. Akadémiai Kiadó, Budapest, 68.

Bartos Károly (2000): Történelemtankönyvek és taneszközök a dualizmus korában. Történelempedagógiai Füzetek, 7. Magyar Történelmi Társulat Tanári Tagozata - ELTE BTK, Budapest, 80.

Biriszló Bence és Szabó Melinda (2012): Mika Sándor (1859-1912). Kézirat.

Domanovszky Sándor (1912): Mika Sándor †. Történeti Szemle, I. évf. 3. sz. 479.

Domanovszky Sándor (1927): Az ókor története Kr. u. 180-ig a középiskolák IV. osztálya számára. Királyi Magyar Egyetemi Nyomda. Budapest.

Domanovszky Sándor (1928): Világtörténelem a katonacsászárok korától a középkori intézmények virágkoráig. A középiskolák V. osztálya számára. Királyi Magyar Egyetemi Nyomda, Budapest.

Domanovszky Sándor (1929): Világtörténelem a középkori intézmények hanyatlásától a felvilágosodás koráig. A középiskolák VI. osztálya számára. Királyi Magyar Egyetemi Nyomda, Budapest.

Domanovszky Sándor (1930): Világtörténelem. A francia forradalom kitörésétől napjainkig a középiskolák VII. osztálya számára. Királyi Magyar Egyetemi Nyomda, Budapest.

Garai Imre (2011): A magyar középiskolai tanári szakma kialakulása. Az Eötvös Collegium helye a magyar tanárképzésben a századfordulón. In: Horváth László, Laczkó Krisztina és Tóth Károly (szerk.): Lustrum. Ménesi út 11-13. Solemnia aedificii a.D. MCMXI inaugurati. Typotex Kiadó-Eötvös Collegium, Budapest. 176-202.

Glatz Ferenc (1989): Történészképzés az Eötvös Kollégiumban. In: Nagy József Zsigmond és Szijártó István (szerk.): Tanulmányok az Eötvös Kollégium történetéből. Eötvös József Kollégium, Budapest. 41-50. (Eötvös Füzetek 10.) 
Hanthó Lajos (1874): Olvasókönyv a hazai tankönyvet tárgyazó összes tankönyvekhez. Csanád Egyházmegyei Könyvnyomda, Temesvár.

Katona András (2006): Képek és arcképek a magyarországi történelemtanítás múltjából III. A rendszeres történelemtanítás meghonosodása az önkényuralom és dualizmus korának Magyarországán a századfordulóig (1849-1902). Tanári Kincsestár. Történelem. Raabe Kft. Budapest, január 26.

Magyar történelmi olvasókönyv I-II. rész. 1905-1907; Történelmi olvasókönyv III-VI. rész. 1908-1910. Madzsar Imre, Szentpéteri Imre, Szigeti Gyula és Szabó Dezső közremüködésével szerkeszti: Mika Sándor. Lampel R. Kk. (Wodianer F. és Fiai) R. T. Könyvkiadóvállalata, Budapest.

Mann Miklós (1993): Kultúrpolitikusok a dualizmus korában. Országos Pedagógiai Könyvtár és Múzeum, Budapest, 100.

Marczell Ágoston - Szolomájer Tasziló (1927): Egyetemes történelem I. rész a gimn., reálgimn. és reálisk. IV. osztálya számára. Szent István-Társulat, Budapest.

Marczell Ágoston - Szolomájer Tasziló (1928): Egyetemes történelem II. rész a gimn., reálgimn. és reálisk. $V$. osztálya számára. Szent István-Társulat, Budapest.

Marczell Ágoston - Szolomájer Tasziló (1929): Egyetemes történelem III. rész a gimn., reálgimn. és reálisk. VI. osztálya számára. Szent István-Társulat, Budapest.

Marczell Ágoston - Szolomájer Tasziló (1930): Egyetemes történelem IV. rész a gimn., reálgimn. és reálisk. VII. osztálya számára. Szent István-Társulat, Budapest.

Mika Sándor - Marczinkó Ferenc (1927): Világtörténelem. 1. kötet. Középiskolák IV. osztálya számára. Lampel, Budapest.

Mika Sándor - Marczinkó Ferenc (1928): Világtörténelem. 2. kötet. Középiskolák V. osztálya számára. Lampel, Budapest.

Mika Sándor - Marczinkó Ferenc (1929): Világtörténelem. 3. kötet. Középiskolák VI. osztálya számára. Lampel, Budapest.

Mika Sándor - Marczinkó Ferenc (1930): Világtörténelem. 4. kötet. Középiskolák VII. osztálya számára. Lampel, Budapest.

Mika Sándor (1859-1912) (1912): Századok, 46. évf. 5. sz. 398-400.

Romsics Ignác (2011): Clio büvöletében. A magyar történetírás a 19-20. században-nemzetközi kitekintéssel. Osiris Kiadó, Budapest, 114., 116., 165., 182-183., 316.

Szádeczky Lajos (1885): A Magyar Történeti Congressus naplója. A Magyar Történelmi Társulat 1885. júl. 3-6. napján Budapesten tartott Congressusának irományai. Századok, XIX. évf. okt. 189-190.

Szebenyi Péter (1970): Feladatok - módszerek - eszközök. Visszapillantás a hazai történelemtanitás múltjára. Tankönyvkiadó, Budapest. 56-57.

\section{Mednyánszky Dénes Könyvtár és Levéltár (MDKL)}

54. doboz 102/a. Az Eötvös Collegium tanári karának gyüléseiről készült jegyzőkönyvek, 1897-1927.

40. doboz 71/3. dosszié. Mika Sándor személyi anyaga, 1895-1912.

41. doboz 72/3-4. dosszié. Tiszteletdíjas tanárok személyi anyagai, 1895-1945. 
52. doboz 101/a-c. Az Eötvös Collegium tanári karának jelentései, 1895-1908.

88. doboz 185/1. dosszié. Az Eötvös Collegium történetére vonatkozó iratok, 1895.

Evangélikus Országos Levéltár (továbbiakban EOL) Egyetemes Tanügyi Bizottság 9. doboz. Iratok 1930-1931. 17. és 18. csomó.

\section{Magyar Tudományos Akadémia Kézirattár és Régi Könyvek Gyüjteménye (MTAKK)}

Szekfü Gyula (Sine anno): Mika Sándor (1859-1912). Kézirat. Ms. 5982/116-117.

Szekfü Gyula (2001): Mika Sándor (1859-1912) : visszaemlékezés a pályakezdésre 1948. In: Szekfü Gyula. Vál., sajtó alá rend., a bevezetést írta Dénes Iván Zoltán. Budapest: Új Mandátum, p. 167-175. (Magyar panteon; 10.)

\section{Iskolai értesitök}

A balassagyarmati M. Kir. Áll. Balassi Bálint Reálgimnázium XXXI. évi értesítője. Közli: Wiesinger Károly kir. igazgató. Balassagyarmat, 1931, 43-46.

A Bányai Ág. Hitv. Ev Egyházkerület Aszódi Petőfi Reálgimnáziumának értesítője az 1930-31. tanévröl. Szerkesztette: Dr. Oravecz Ödön az 1926-32. évkörre vál. igazgató. Aszód, 1931, 49-51.

A Ceglédi M. Kir. Állami Kossuth Reálgimnázium értesítője az 1930-31. évről. Szerkesztette: Szőnyi Sándor igazgató. Cegléd, 1931, 48-49.

A Csongrádi M. Kir. Állami Szent Imre Reálgimnázium értesítője az 1931-32. iskolai évről. Közzéteszi: Úr Márton h. igazgató. Csongrád, 1932, 30-32.

A Debreceni M. Kir. Állami Fazekas Mihály Reáliskola ötvenkilencedik értesítője az 1931-1932. iskolai évről. Közzétette: Dr. Zalai János kir. igazgató. Debrecen, 1932, 28-29.

A gyöngyösi állami Koháry István Reálgimnázium az 1930-1931. Közzéteszi: Erdős Tivadar igazgató. Gyöngyös, 1931, 60-61.

A Győri M. Kir. Állami Révai Miklós Reáliskola LVIII. értesítője az 1930/31. iskolaévről. Közli: Simon Miklós kir. igazgató. 86.

A hatvani M. Kir. Állami Reáliskola értesítője. 1920-31. iskolai év. (IV. évfolyam) Közzéteszi: Szilvásy János igazgató. Hatvan, 1931, 42-44.

A Jászberényi Magyar Királyi Állami József nádor Reálgimnázium értesítője az 1930-1931. iskolai évről. Közzéteszi: Józsy Ferenc. Jászberény, 1931, 82-86.

A kecskeméti M. Kir. Állami Katona József Reáliskola 1930-31. tanévi értesítője. Közli: Ifj. Gáspárics Lajos kir. igazgató. Kecskemét. 51-52.

A kispesti M. Kir. Állami Deák Ferenc Reálgimnázium értesítője az 1931-32. iskolai évről. Közli: Dr. Resch Aurél igazgató. Kispest, 1932, 11.

A kisvárdai M. Kir. áll. Bessenyei György Reálgimnázium és a vele kapcsolatos állami internátus huszonegyedik évi értesítője az 1931-32. isk. évről. Közzéteszi: Dr. Tóth József igazgató. Kisvárda, 1932, 70-72. 
A kőszegi M. Kir. „Hunyadi Mátyás” Reáliskolai Nevelőintézet értesítője 1931-32. iskolai év. Kiadja: az intézet igazgatósága. Kőszeg, 1932, 35.

A m. kir. Rákóczi Ferenc Reáliskolai Nevelőintézet Értesítője 1932-33. Sopron, 1933, 42-45.

A makói M. Kir. Állami Csanád vezér Reálgimnázium és vele kapcsolatos Állami Internátus XXXVI. értesítője. 1930-31. iskolai év. Közzétette: Buday Géza m. igazgató. Makó, 1931, 75-76.

A m. Kir. Állami Hunfalvy János Reáliskola XV. évi értesítője az 1931-32. iskolai évről. Közzéteszi: Galgói Rácz Viktor kir. igazgató. Miskolc, 1932, 44-46.

A nagykállói M. Kir. Állami Szabolcsvezér Reálgimnázium XXXIII. értesítője az intézet fennállásának 60-ik évében. Az 1929-30. iskolai évről. Összeállította: Árvay Ede mb. igazgató. Nagykálló, 42-43.

A pécsi M. Kir. Zrínyi Miklós Reáliskolai Nevelőintézet értesítője. Közzéteszi: az iskola igazgatósága. 1931-1932. tanév. Pécs, 1932, 43-44.

A Pécsi Magyar Királyi Középiskolai Tanárképzőintézeti gróf Széchenyi István Gyakorló Reáliskola 1931-32. tanévi értesítője. Közzéteszi: Dr. Horváth Viktor igazgató. Pécs, 1932, 49-50.

A pesterzsébeti M. Kir. Állami Kossuth Lajos Reálgimnázium értesítője az 1931-1932. iskolai évről. Közzétette: Dr. Stagl Arthur áll. reálgimnáziumi igazgató. Pesterzsébet, 1932, 28-29.

A Rákóczi Ferenc m. kir. reáliskolai nevelőintézet értesítője. 1927-28. Sopron. 57-58.

A rákospalotai Wágner Manó Nyilvános Reálgimnázium értesítője az 1930-1931-i tanévröl. Közli: Wágner Aurél igazgató. Athenaeum. 46-47.

A salgótarjáni Chorin Ferenc Reálgimnázium értesítője az 1930/31. tanévről. Összeállította: Dr. Szabó Lajos igazgató. Salgótarján, 1931, 55-57.

A soproni áll. Széchenyi István Reálgimnázium 56. sz. értesítője az 1930/31. iskolai évröl. Szerkesztette: Lauringer Ernő igazgató. Sopron, 1931, 45-47.

A sümegi M. Kir. Áll. Kisfaludy Sándor Reáliskola LXXIV. értesítője. Közzétette: Sabján János igazgató. Sümeg, 1931, 45-46.

A szarvasi ág. hitv. evang. Vajda Péter Gimnázium értesítője az 1931-32. tanévről. Közzéteszi: Raskó Kálmán igazgató. Szarvas, 1932.

A szegedi M. Kir. áll. Baross Gábor Reáliskola LXXX. jubiláris értesítője az 1931-32. tanévröl. Közzéteszi: Dr. Firbás Oszkár mb. igazgató. Szeged, 1932, 40-41.

A szegedi M. Kir. Állami Klauzál Gábor Reálgimnázium harmincnegyedik értesítője. Közzéteszi: Somogyi József igazgató. Szeged, 1932, 72-73.

A székesfehérvári Magy. Kir. Állami Ybl Miklós Reáliskola LXXVIII. értesítője az 193132. tanévről. Közzétette: Dr. Bezdek József igazgató. Székesfehérvár, 1932, 21-22.

A szekszárdi M. Kir. Áll. Garay János Reálgimnázium XXXVI. évi értesítője az 1931-32. tanévről. Közzéteszi: Róder Pál igazgató. Szekszárd, 1932, 47-48.

A szentgotthárdi Magyar Királyi Állami Reálgimnázium értesítője az 1931-32. évről. Közzéteszi. Mathiasz Artúr igazgató. Szentgotthárd, 1932, 38.

A szolnoki M. Kir. Állami Verseghy Ferenc Reálgimnázium értesítője az 1930-31. tanévröl. Közzéteszi: Wollek Géza igazgató. Szolnok, 1931, 59-61. 
A szombathelyi M. Kir. áll. Faludi Ferenc Reáliskola értesítője az 1931-32. iskolai évről. Közzétette: Dr. Perepatits István kir. igazgató. Szombathely, 1932, 68-69.

A zalaegerszegi M. Kir. Állami Deák Ferenc Reálgimnázium XXXVI. értesítője az 1931-32. iskolai évröl. Szerkesztette: Péterffy Béla igazgató. Zalaegerszeg. 17-19.

Az egri Magyar Kir. Állami Dobó István Reáliskola 41. évi értesítője az 1930-1931. iskolai évről. Közli: Fejér József dr. megbízott igazgató. Eger, 1931, 47-48.

Az újpesti M. Kir. Állami Könyves Kálmán Reálgimnázium értesítōje az 1930-31. iskolai évről. (XXV. évfolyam). Közzéteszi: Dr. Zibolen Endre igazgató. Ujpest, 1931, 73-74.

Budapest-vidéki tankerület. Az esztergomi államilag segélyezett községi Szent Imre Reáliskola értesítője az intézet fennállásának 74-ik évéről 1930-31. Közzéteszi: Obermüller Ferenc igazgató. Esztergom, 1931, 70-72. 